\title{
Suppressive Effects of Oral Administration of Heat-Killed Lactobacillus acidophilus on T Helper-17 Immune Responses in a Bovine $\beta$-Lactoglobulin-Sensitized Mice Model
}

\author{
Ai-li Li, Xiang-chen Meng,* Cui-cui Duan, Gui-cheng Huo, Quan-ling Zheng, and Dan Li \\ Key Laboratory of Dairy Science, Ministry of Education, College of Food Science, Northeast Agriculture University; \\ 59 Mucai Street, Xiangfang District, Harbin, Heilongjiang 150030, China. \\ Received May 11, 2012; accepted November 10, 2012; advance publication released online December 3, 2012
}

The present study was planned to explore the effect of Lactobacillus $($ L.) acidophilus on the T helper-17 (Th17) immune response in a mouse model of $\beta$-lactoglobulin $(\beta$-lg) allergy. Bovine $\beta$-lg sensitised BALB/c mice were orally administered with different doses of heat-killed $L$. acidophilus (low, $5 \times 10^{7}$ colony forming unit (CFU); medium, $5 \times 10^{8} \mathrm{CFU}$; high, $5 \times 10^{9} \mathrm{CFU}$ ) in $200 \mu \mathrm{L}$ of phosphate buffered saline (PBS) three times a week, starting from 1 week before $\beta$-lg sensitisation for 4 weeks. After the allergen challenge, the numbers of blood eosinophils and neutrophils were examined by light microscope; the levels of cytokine (interleukin (IL)-12, IL-4, tumor growth factor (TGF)- $\beta$, IL-10, IL-6 and IL-17A), total immunoglobulin E (IgE) and $\beta$-lg-specific IgE contents in the serum were measured with enzyme-linked immunosorbent assay (ELISA); The mRNA expression levels of TGF- $\beta$, IL-17A,CD25, Foxp3, retinoic acid-related orphan receptor $\gamma t(R O R \gamma t)$ and IL-10 were analyzed using real-time polymerase chain reaction (PCR). The results showed that oral administration of $L$. acidophilus suppressed hypersensitivity responses, attenuated the numbers of inflammatory cells and inhibited IgE production. We found up-regulation of TGF- $\beta$ and down-regulation of IL-17A in the serum of $L$. acidophilus-treated group, along with IL-6 levels was significantly decreased than that of the allergy group $(p<0.05)$. Moreover, the mRNA expression levels of CD25, forkhead box P3 and TGF- $\beta$ were significantly higher in the spleen of $L$. acidophilus-treated group, while the mRNA expression levels of IL-17A, ROR $\gamma$ t and IL-10 were significantly lower than that in the allergy group $(p<0.05)$. In conclusion, the suppression of major allergic symptoms by oral administration of L.acidophilus was probably due to improve the regulatory $T$ (Treg)/Th17 balance and inhibit the IL-6 production. kin-6

Key words Lactobacillus acidophilus; $\beta$-lactoglobulin allergy; $\mathrm{T}$ helper-17 cell; regulatory $\mathrm{T}$ cell; interleu-

The prevalence of cow's milk allergy continues to increase in the developed world and constitutes a common health problem among children. ${ }^{1)}$ It is an adverse reaction to the proteins present in milk, where $\beta$-lactoglobulin $(\beta$-lg) is considered to be the dominant cow's milk allergen. ${ }^{2)}$ Bovine $\beta$-lg allergy generally corresponds to an inappropriate immune response characterized by a disruption of the Th1/Th2 balance toward a $\mathrm{Th} 2$ profile that results in the production of immunoglobulin $\mathrm{E}$ (IgE) ${ }^{3,4)}$ Recent studies on $\mathrm{T}$ helper cells including $\mathrm{T}$ helper-17 (Th17) and $\mathrm{CD} 25^{\text {high }}$ forkhead box $\mathrm{P}^{+}$(Foxp3 ${ }^{+}$) regulatory $\mathrm{T}$ cells (Treg cells) have received greater interests in better understanding allergic diseases. ${ }^{5,6)}$ Th17 cells described as $\mathrm{CD} 4^{+} \mathrm{CD} 17^{+}$cells produce the signature cytokine interleukin-17 (IL-17) and participate in the induction of inflammation. ${ }^{7}$ While Treg cells participate in maintain tolerance to self-components by contact-dependent suppression or the release of anti-inflammatory cytokines such as IL-10 and tumor growth factor (TGF)- $\beta{ }^{8)}$ Tregs and Th17 cells have the same T-cell precursors and the opposite effects on inflammation and immunologic tolerance. ${ }^{9)} \mathrm{He}$ et al. ${ }^{10)}$ showed that the intraperitoneal ovalbumin with alum immunization could induce Th17 cells in murine spleen. Cheung et al. ${ }^{11)}$ found that Th17 cells were increased not only in neutrophilic airway inflammation but also in Th2 cell-mediated eosinophilic airway inflammation in a murine asthma model. Yamamoto et al. ${ }^{12)}$ found that Treg/Th17 imbalance participated in the pediatric patients with food allergies. Therefore, further investigations on the

The authors declare no conflict of interest. mechanism of Treg/Th17 immune responses are important in the studies of allergic disorders.

Lactobacilli have been widely used as adjunctive therapy of allergic diseases. ${ }^{13)}$ Recent studies have shown the immunomodulation mechanism of lactobacilli for the beneficial effect on allergic disease model animals is apparently not confined to the simple notion of the restoration of the Th1/Th2 balance. For instance, Kwona et al. ${ }^{14)}$ provided evidence that some lactobacilli might induce Foxp $3^{+}$regulatory $\mathrm{T}$ cells to have a beneficial effect on allergy and autoimmune diseases. Jan et $a l .{ }^{15)}$ reported that oral administration with Lactobacillus $(L$. gasseri can attenuate major characteristics of allergen-induced airway inflammation and IL-17 pro-inflammatory immune response in a mouse model of allergic asthma. Moreover, Patricia López et al. ${ }^{16)}$ support the fact that specific food and commensal bacteria may play a role in balancing the development of Treg and Th17 cell compartments in the intestine. However, whether the effect of lactobacilli can modulate the Treg/Th17 imbalance in $\beta$-lg-sensitized mice is currently unknown.

Today, the precise mechanism of lactobacilli-induced immunomodulation has not been fully elucidated. Previous studies demonstrated that oral treatment of $\beta$-lg-sensitized mice with heat-killed L. acidophilus KLDS 1.0738 could significantly attenuate hypersensitivity responses and inhibit IgE production. ${ }^{17)}$ Consequently, we were particularly interested in investigating the capacity of this microorganism in down-regulating Th17 immunity. In this study, we administered $\beta$-lg-sensitized mice with various doses of heat-killed $L$. acidophilus KLDS 1.0738 and measured the numbers of inflammatory cells in 


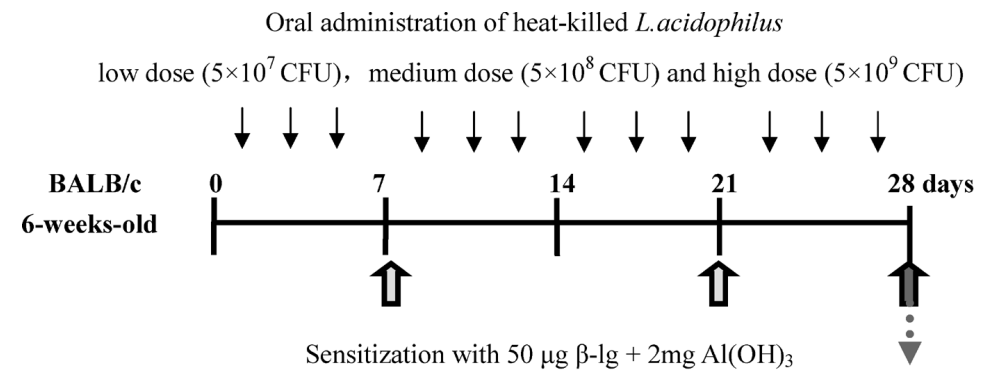

Intragastrical challenge by $\beta$-lg

Serum and splenocytes collection

Fig. 1. Schedule for Immunization with $\beta$-lg and Administration of Heat-Killed L. acidophilus KLDS 1.0738

Day 0 is defined as the start of the experiment. Balb/c mice were orally treated with $L$. acidophilus before sensitization with $\beta$-lg developed. Spleens and blood samples were taken after intragastrical challenge.

blood; level of various cytokines and IgE in serum; and TGF$\beta$, IL-17A, CD25, Foxp3, retinoic acid-related orphan receptor $\gamma \mathrm{t}(\mathrm{ROR} \gamma \mathrm{t})$ and IL-10 gene expression in spleen.

\section{MATERIALS AND METHODS}

Animals Female BALB/c mice (6-week-old) were obtained from the Centre of Experimental Animals, Tumor Hospital of Harbin Medical University (Harbin, China). Mice were housed six per cage at $20-24^{\circ} \mathrm{C}$ on a 12 -h light and 12 -h dark cycle, with unlimited supplies of food and water sterilized by irradiation and autoclaving. All animal procedures were approved by the Institutional Animal Care and Use Committee of Northeast Agricultural University.

Microorganisms The L. acidophilus strain KLDS 1.0738 was obtained from key laboratory of Dairy Science of Ministry of Education, where the strain was originally isolated. The microorganism was cultivated for $16 \mathrm{~h}$ at $37^{\circ} \mathrm{C}$ in MRS broth (Difco), collected by centrifugation, and then washed three times with phosphate buffer saline (PBS). Then the microorganisms were killed by heating at $100^{\circ} \mathrm{C}$ for $20 \mathrm{~min}$. The stock suspensions, which contained approximately $3 \times 10^{10}$ colony-forming unit (CFU)/mL for KLDS 1.0738, were stored at $-80^{\circ} \mathrm{C}$ until used.

Sensitization and Oral Administration of Heat-Killed Bacteria Female BALB/c mice ( $n=6$ per group) were intraperitoneally injected on day 7 and 21 with $50 \mu \mathrm{g}$ of $\beta-\lg$ (Sigma) adsorbed on $2 \mathrm{mg}$ of $\mathrm{Al}(\mathrm{OH})_{3}$ in $200 \mu \mathrm{L}$ of sterile PBS. Treatment groups received oral administration of low dose $\left(5 \times 10^{7} \mathrm{CFU}\right)$, medium dose $\left(5 \times 10^{8} \mathrm{CFU}\right)$ and high dose $\left(5 \times 10^{9} \mathrm{CFU}\right)$ of heat-killed L. acidophilus KLDS 1.0738 suspended in $200 \mu \mathrm{L}$ PBS three times a week via a gavage needle, started from day 0 and continued until day 28. As a control, $200 \mu \mathrm{L}$ of PBS was administered to mice. Allergen challenge was performed with mice on days 28 by intragastrical administration of PBS or two times of $\beta-\lg (20 \mathrm{mg} / \mathrm{mouse})$ given $30 \mathrm{~min}$ apart. Two hours after final oral $\beta$-lg challenge, blood and tissue samples were collected for further analysis (Fig. 1) .

Evaluation of Symptoms Within an hour following the final oral $\beta$-lg challenge, hypersensitivity symptoms were evaluated by using a scoring system modified slightly from previous reports. ${ }^{18}$ The scores were as follows: $0=$ no symptoms; $1=$ scratching and rubbing around the nose and head; $2=$ puffiness around the eyes and mouth and pilar erecti; $3=$ decreased activity with increased respiratory rate; $4=$ wheezing and labored respiration; $5=$ cyanosis around the mouth and the tail; and $6=$ death.

Inflammatory Cell Counts On day 28, the blood samples were collected by taking the eyeball of each group mice for routine laboratory tests of eosinophil and neutrophil counts. Differential cell counts were obtained using a cytospin preparation, stained with May-Grünewald-Giemsa and examined under light microscope.

Measurement of Immunoglobulins and Cytokines The levels of cytokines (IL-12, IL-4, TGF- $\beta$, IL-10, IL-6 and IL-17A) in serum were measured using commercial enzyme linked immunosorbent assay (ELISA) kits (R\&D, Minneapolis, MN, U.S.A.) according to the manufacturer's protocols. A standard curve was generated using recombinant cytokine for each assay. The concentration of total $\mathrm{IgE}$ in serum was also measured using a mouse IgE ELISA quantitation kits (Bethyl Laboratories, Montgomery, TX, U.S.A.). Each sample was performed in triplicate.

Bovine $\beta$-lg-specific IgE were evaluated by ELISA in accordance with the methods of Duan et al. ${ }^{19)} \beta$-Lg-specific $\operatorname{IgE}$ titer was calculated from the comparison with hyperimmunized mouse serum. The hyperimmunized serum was obtained from mice that were intraperitoneally immunized with $\beta$-lg adsorbed onto $\mathrm{Al}(\mathrm{OH})_{3}$. $\beta$-Lg-Specific IgE of the sample was expressed as a percentage.

Real-Time Quantitative Polymerase Chain Reaction (PCR) Total RNA was extracted from spleens and reversetranscribed into cDNA using random hexamer primers and RNase H-reverse transcriptase (TaKaRa, Dalian, China) according to the manufacturer's instructions. For real-time PCR, primers were designed (Table 1) and entered into NCBI BLAST database to ensure that it was specific for the target mRNA transcription and then synthesized by The Beijing Genomics Institute (Beijing, China). PCR were performed using TaKaRa real-time PCR regent box (TaKaRa) in a total volume of $20 \mu \mathrm{L}$. PCR conditions for IL-17A, IL-10, Foxp3, CD25 and TGF- $\beta$ were $95^{\circ} \mathrm{C}$ for $30 \mathrm{~s}, 40$ cycles of $95^{\circ} \mathrm{C}$ for $15 \mathrm{~s}, 60^{\circ} \mathrm{C}$ for $30 \mathrm{~s}, 72^{\circ} \mathrm{C}$ for $45 \mathrm{~s}$, but the annealing temperature of $\mathrm{ROR} \gamma \mathrm{t}$ was $64^{\circ} \mathrm{C}$. $\beta$-Actin gene transcription was used as a housekeeping control for normalization.

Statistical Analysis All results were expressed as the mean \pm S.D. One-way ANOVA test was performed to determine the statistical significance. Data between two groups were compared by Student's $t$-test or Mann-Whitney's $U$-test. A $p$-value $<0.05$ was considered to be significant. SPSS 13.0 
Table 1. Primers of Real-Time PCR

\begin{tabular}{|c|c|c|}
\hline Name & & Sequence $\left(5^{\prime} \rightarrow 3^{\prime}\right)$ \\
\hline \multirow[t]{2}{*}{ IL-17A } & Forward primer & AGGGAGAGCTTCATCTGTGG \\
\hline & Reverse primer & AGATTCATGGACCCCAACAG \\
\hline \multirow[t]{2}{*}{ IL-10 } & Forward primer & СССTTTGCTATGGTGTCCTT \\
\hline & Reverse primer & TGGTTTCTCTTCCCAAGACC \\
\hline \multirow[t]{2}{*}{ Foxp3 } & Forward primer & TTTCCAAGAACGGGCATTA \\
\hline & Reverse primer & TGTGGCTGACTGAGGGTGT \\
\hline \multirow[t]{2}{*}{ CD25 } & Forward primer & ACACCTGTAAGCCCAGCTCT \\
\hline & Reverse primer & TGGAAAGGTTGAGGGGTAAG \\
\hline \multirow[t]{2}{*}{ TGF- $\beta$} & Forward primer & ACCATGCCAACTTCTGTCTG \\
\hline & Reverse primer & CGGGTTGTGTTGGTTGTAGA \\
\hline \multirow[t]{2}{*}{$\mathrm{ROR} \gamma \mathrm{t}$} & Forward primer & AGAAAGAAAAGGGGAACTGG \\
\hline & Reverse primer & CTATTGTGGCTGCTGAGTTC \\
\hline \multirow[t]{2}{*}{$\beta$-Actin } & Forward primer & CGCAAAGACCTGTATGCCAAT \\
\hline & Reverse primer & GGGCTGTGATCTCCTTCTGC \\
\hline
\end{tabular}

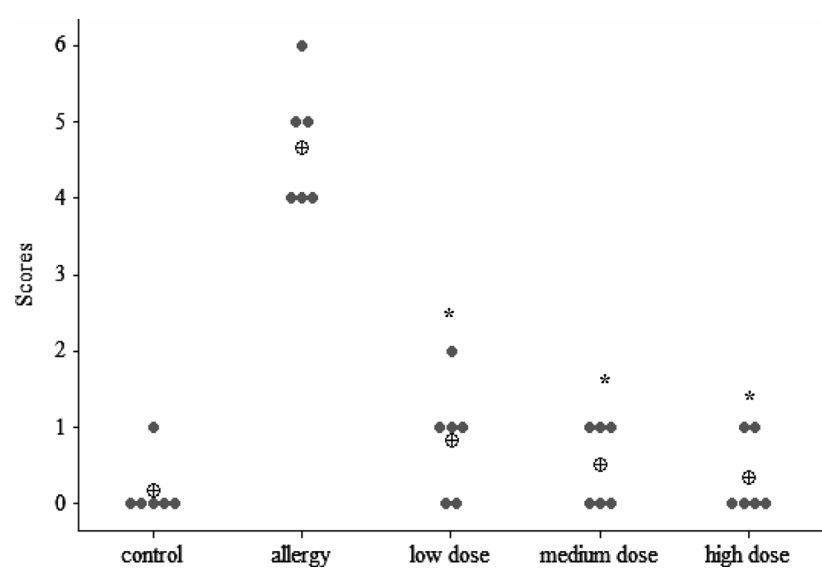

Fig. 2. Scores of Hypersensitivity Symptoms

Each point represented an individual mouse. Mice were intraperitoneally injected with $\beta$-lg absorbed on $\mathrm{Al}(\mathrm{OH})_{3}$ gel on days 7 and 21. Heat-killed L. acidophilus was given orally to mice at low dose $\left(5 \times 10^{7} \mathrm{CFU}\right)$, medium dose $\left(5 \times 10^{8} \mathrm{CFU}\right)$ and high dose $\left(5 \times 10^{9} \mathrm{CFU}\right)$ from day 0 to day 28 . Allergen challenge was performed on days 28 by intragastrical administration of PBS or $20 \mathrm{mg} \beta$-lg. Hypersensitivity symptoms was evaluated based on a scoring system. Data are means \pm S.D. $(n=6)$ $* p<0.05$ versus allergy group.

for Windows software (SPSS Inc., Chicago, IL, U.S.A.) was used for data analysis.

\section{RESULTS}

Effect of Oral Administration of L. acidophilus on the Active Phase of $\boldsymbol{\beta}$-lg-Sensitized Mice Bovine $\beta$-lgsensitized mice appeared listlessness, weight loss, death and other symptoms. And the average hypersensitivity score in allergy group was significantly higher than that observed in control group $(p<0.05)$. Compared to allergy group, treatment with different doses of $L$. acidophilus had weaker reactions (Fig. 2).

The numbers of blood eosinophils and neutrophils in allergy group tended to be significantly higher than that observed in control group $(p<0.05)$. Histopathological findings also showed that its intestinal structural was damaged with inflammatory cell infiltrates (data not shown). In contrast, no significant differences were observed in the numbers of blood eosinophils and neutrophils between high doses of $L$. acidophilus group and control group (Fig. 3).

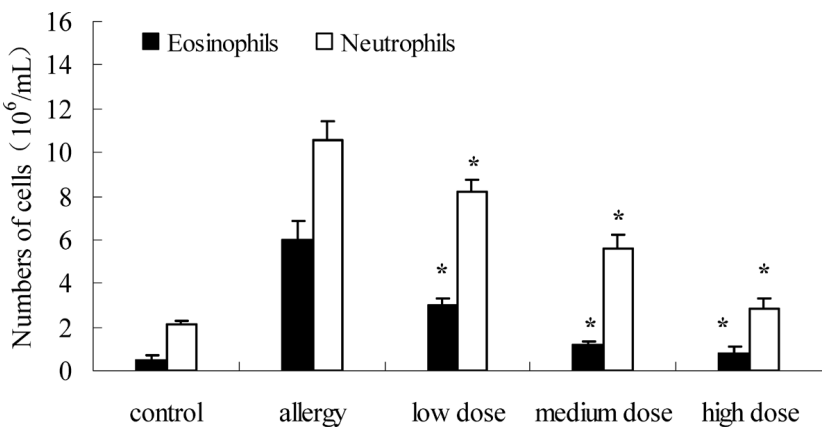

Fig. 3. Effect of Oral Administration of Heat-Killed L. acidophilus on Inflammatory Cell Counts in $\beta$-lg-Sensitized Mice Blood

Mice were intraperitoneally injected with $\beta$-lg absorbed on $\mathrm{Al}(\mathrm{OH})_{3}$ gel on days 7 and 21 . Heat-killed L. acidophilus was given orally to mice at low dose $\left(5 \times 10^{7} \mathrm{CFU}\right)$, medium dose $\left(5 \times 10^{8} \mathrm{CFU}\right)$ and high dose $\left(5 \times 10^{9} \mathrm{CFU}\right)$ from day 0 to day 28. Blood samples were taken after intragastrical challenge, cells were identified and counted. Data are means \pm S.D. $(n=6) .{ }^{*} p<0.05$ allergy group.

Effect of Oral Administration of Heat-Killed L. acidophilus on IgE and Cytokine Production To determine whether the attenuated allergen-induced Th17 cytokine response was a result of systemic immunological changes due to L. acidophilus ingestion, we measured the changes in serum antibody concentration and cytokine production.

As shown in Fig. 4, compared to control group, $\beta$-lg sensitized mice produced higher amount of total IgE and $\beta$-lg-specific IgE antibodies and oral administration of $L$. acidophilus suppressed antibodies production in a dosedependent manner. Oral administration of L. acidophilus at high dose level $\left(5 \times 10^{9} \mathrm{CFU}\right)$ significantly inhibited total $\mathrm{IgE}$ and $\beta$-lg-specific IgE production compared with allergy group $(p<0.05)$.

We found that serum concentration of the Th2 response cytokine (IL-4), novel proinflammatory cytokine (IL-17A), IL-6 and IL-10 were significantly elevated in allergy group compared to control group $(p<0.05)$. The levels of Th1 response cytokine (IL-12) was not significantly changed compared with that of control group. While oral administration of different dose of $L$. acidophilus in $\beta$-lg sensitized mice significantly attenuated the increase in IL-4, IL-10, IL-6 and IL-17A levels. In contrast, the levels of TGF- $\beta$ were significantly elevated in administered L. acidophilus group when compared with allergy group $(p<0.05)$. 


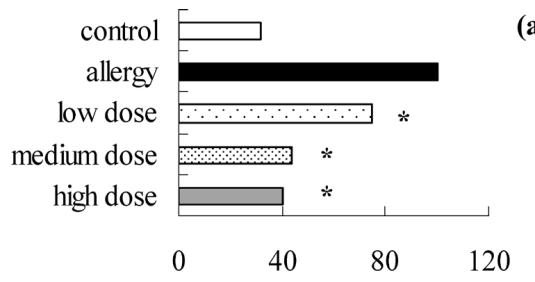

$\beta$-lg-specific $\operatorname{IgE}(\%$ of allergy group)
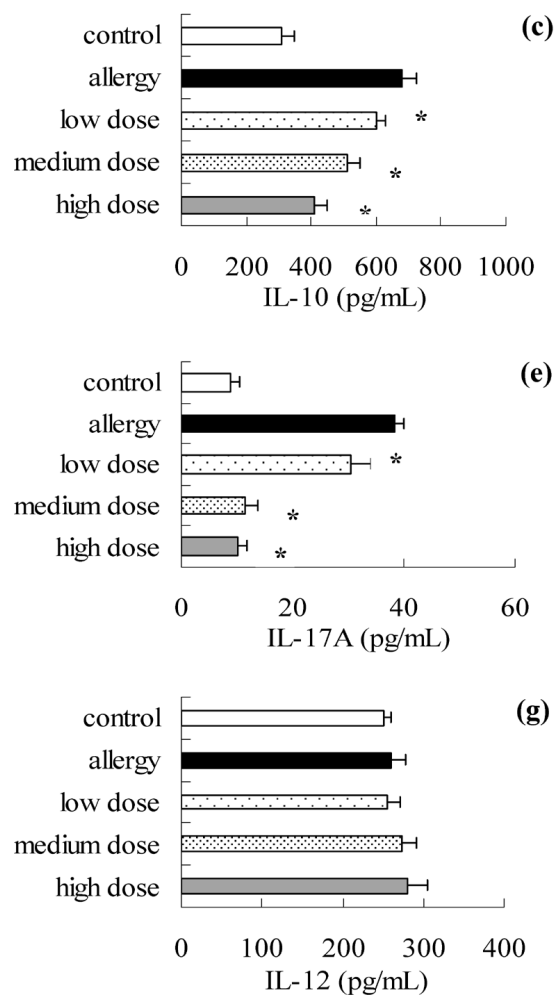

(g)

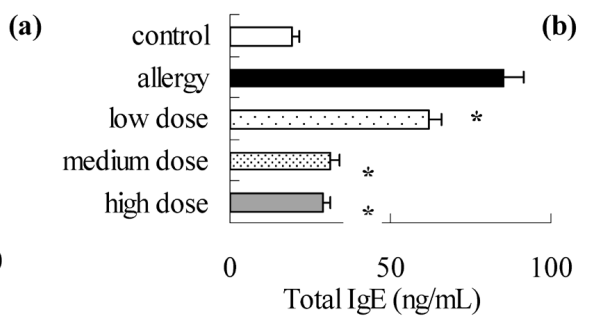

(c)
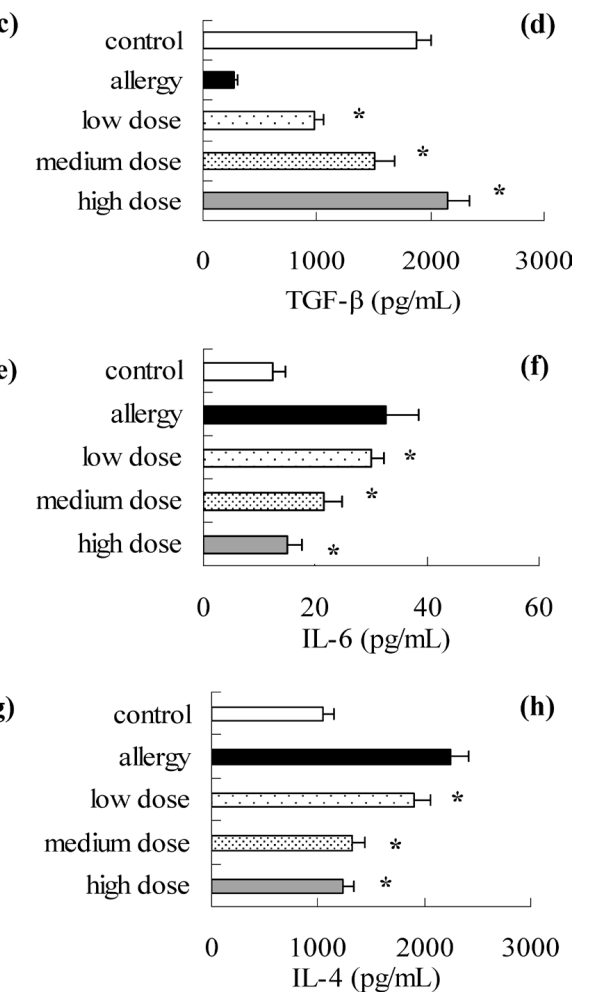

Fig. 4. Effect of Oral Administration of Heat-Killed L. acidophilus on Cytokines and IgE Production in $\beta$-lg-Sensitized Mice Serum

Mice were intraperitoneally injected with $\beta$-lg absorbed on $\mathrm{Al}(\mathrm{OH})_{3}$ gel on days 7 and 21 . Heat-killed L. acidophilus was given orally to mice at low dose $\left(5 \times 10^{7} \mathrm{CFU}\right)$, medium dose $\left(5 \times 10^{8} \mathrm{CFU}\right)$ and high dose $\left(5 \times 10^{9} \mathrm{CFU}\right)$ from day 0 to day 28 . Serum were taken after intragastrical challenge. $\beta$-lg-specific IgE (a), total IgE (b) and cytokine IL-10 (c), TGF- $\beta$ (d), IL-17A (e), IL-6 (f), IL-12 (g) and IL-4 (h) levels were measured using the respective ELISA kits. Data are means \pm S.D. $(n=6) .{ }^{*} p<0.05$ versus allergy group.

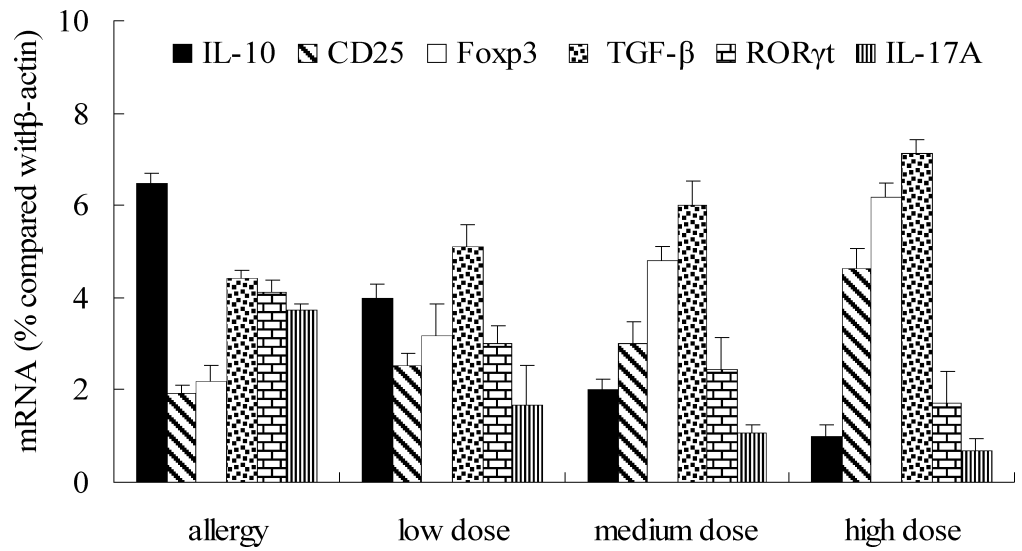

Fig. 5. The mRNA Expression of IL-10, CD25, Foxp3, TGF- $\beta$, ROR $\gamma$ t and IL-17A in Spleen Were Assayed by Real-Time PCR

Mice were intraperitoneally injected with $\beta$-lg absorbed on $\mathrm{Al}(\mathrm{OH})_{3}$ gel on days 7 and 21 . Heat-killed $L$. acidophilus was given orally to mice at low dose $\left(5 \times 10^{7} \mathrm{CFU}\right)$, medium dose $\left(5 \times 10^{8} \mathrm{CFU}\right)$ and high dose $\left(5 \times 10^{9} \mathrm{CFU}\right)$ from day 0 to day 28 . Spleen were collected on day 28 , the relative levels of IL-10, CD25, Foxp3, TGF- $\beta$, ROR $\gamma \mathrm{t}$ and IL-17A mRNA in mouse spleen was calculated and expressed at the percentage of mRNA to $\beta$-actin. Data are means \pm S.D. $(n=6)$.

Effect of Oral Administration of Heat-Killed L. acidophilus on IL-17A, IL-10, Foxp3, CD25, TGF- $\beta$ and ROR $\gamma \mathrm{t}$ Expression Furthermore, we analyzed the effect of orally administered L. acidophilus on the molecular changes in response to the Treg/Th17 imbalance. We detected the mRNA expression of their respective signature transcription factors 
Foxp3 and ROR $\gamma$ t, their respective relative cytokines TGF- $\beta$, CD25, IL-10 and IL-17A in splenocytes by real-time quantitative PCR (Fig. 5). The mRNA expression levels of Foxp3, CD25 and TGF- $\beta$ in high or medium dose of L. acidophilus group were significantly higher $(p<0.05)$. Consistently, IL17A, ROR $\gamma$ t and IL-10 mRNA expression were significantly decreased than that in the allergy group $(p<0.05)$.

\section{DISCUSSION}

Accumulating data suggests that some lactobacilli have the ability to prevent and alleviate allergic disease. ${ }^{20,21)}$ But the mechanism by which they modulate the immune system is poorly understood. In the present study, we hypothesised that $L$. acidophilus is able to attenuate $\beta$-lg allergy as well as regulate the Treg/Th17 balance in the allergic murine model, which may explain the beneficial response of probiotics supplement in the prevention of allergic diseases.

Bovine $\beta$-lg allergy is a complex inflammatory disease, in which $\mathrm{T}$ cells play a central role in immunoregulation and immunostimulation. $^{22)}$ T-cell subsets can be categorized as Th1, Th2, Th17 and Treg. ${ }^{23)}$ Th1 cells, which produce IL-12 and interferon-gamma (IFN- $\gamma$ ), are involved in cellular immunity. Th2 cells, which produce IL-4 and IL-5, are involved in humoral immunity. ${ }^{24)}$ In pevious studies $\beta$-lg allergy was generally considered to be a Th2-dominant chronic inflammatory disease. ${ }^{25)}$ In our study, increased Th2-cytokine, IgE levels and eosinophils are observed. Recent studies on non-Th1/Th2cell- based mechanisms for the pathogenesis of allergic diseases identified two additional Th cell subsets, Th17 cells and Treg cells. ${ }^{26)}$ Th17 cells, a subset of IL-17-producing T cells, and their key regulator for Th17-cell lineage differentiation is the retinoic acid-related orphan receptor $\gamma \mathrm{t}(\mathrm{ROR} \gamma \mathrm{t}){ }^{27,28)} \mathrm{Treg}$ cells are characterized by the expression of the transcription factor Foxp3, which is induced by TGF- $\beta .{ }^{29)}$ We found that the expression of ROR $\gamma \mathrm{t}$ and related cytokine IL-17A were higher and the expression of Foxp3 and related cytokine TGF- $\beta$ were lower in $\beta$-lg-sensitised mice. In addition, IL-6 levels were clearly increased in allergic mice compared with that in controls. Recent studies suggest that IL-6 plays an important role in determining the type of adaptive immune response, primarily in the differentiation of effector $\mathrm{CD} 4^{+} \mathrm{T}$ cells. ${ }^{30)}$ Pasare and Medzhitov $^{31)}$ indicated that IL- 6 can modulate the intensity of the immune response by inhibiting Treg cells development. McGeachy et al. ${ }^{32)}$ and Ziegler and Buckner ${ }^{33)}$ also showed that IL-6 relieved Foxp3- mediated inhibition of ROR $\gamma$ t, thereby promoting Th17 cell differentiation. These studies further support our results showing that Treg/Th17 imbalance exist in the allergic mice sensitized with $\beta-\lg$, which may be associated with increased production of IL-6.

In this study, the antiallergic properties of heat-killed $L$. acidophilus were investigated. Usually, the antiallergic effect of lactobacilli can be ascribed to a skew of the Th1/Th2 balance in favor of Th1 mediated immunity. ${ }^{34,35)}$ Our data showed that Th2 cytokine production (IL-4) and antibody (total $\operatorname{IgE}$ and $\beta$-lg-specific IgE) production can be decreased after intake of L. acidophilus. In addition, we were able to observe a significant decrease of IL-17A and increased production of TGF- $\beta$ in L. acidophilus-treated mice serum. These observations are supported by subsequent experiments, demonstrating that up-regulation of the IL-17A, ROR $\gamma \mathrm{t}$ expression and down-regulation of the Foxp3, CD25 expression (critical markers of Treg cell activity) after sensitization was successfully reversed following application of L. acidophilus. Thus, we conclude that the inhibitory effect of $L$. acidophilus on allergic response is not only due to the restoration of Th1/Th2 immune balance, but also due to the regulation of Treg cells and Th17 cells. Since IL- 6 may be a key factor indetermining the balance of $\mathrm{CD}^{+} \mathrm{T}$ cells in becoming Treg or inflammatory Th17 cells, ${ }^{36)}$ we analyzed the ability of L. acidophilus strains to inhibit the production of IL-6. In the current study, we found that the oral administration of L. acidophilus to $\beta$-lg-immunized mice significantly inhibited IL-6 production compared with allergy group (Fig. 4f). In accordance with these observations, we suggest that reduction of IL- 6 is a key in inhibiting Th17 cells development and promoting Treg cells differentiation.

It was surprising that IL-10-which is considered to be a main regulatory cytokine and a functional marker for Tregs - was down-regulated correspondingly to the reputed Th17 cytokines, in L. acidophilus-fed animals in response to allergen stimulation. This is a somewhat controversial finding, since in a clinical study ingestion of LGG was associated with high serum IL-10 levels ${ }^{37)}$ and recent reports identify in vitro IL-10-producing regulatory cells as main lineage after Lactobacilli-induced stimulation of dendritic cells. ${ }^{38,39)}$

In conclusion, the L. acidophilus strains that were investigated in this study probably prevent and alleviated allergic symptoms by regulating the Treg/Th17 balance. Moreover, oral administration with L. acidophilus suppress Th17 proinflammatory response may be associated with reduction of IL-6. The exact role of IL-6 production in the antiallergic activity of $L$. acidophilus remains unclear. Therefore, further studies are needed to evaluate the details of the L. acidophilus mechanism of suppression of the Th17 immune response.

Acknowledgements This work was financially supported by National Natural Science Foundation of China (No. 31101267), The Ministry of Education Innovation Team Foundation of China (No. IRT-0959-205) and Innovative Team of Northeast Agricultural University (No. CXT007-2-1).

\section{REFERENCES}

1) Caffarelli C, Baldi F, Bendandi B, Calzone L, Marani M, Pasquinelli P, EWGPAG. Cow's milk protein allergy in children: a practical guide. Ital. J. Pediatr., 36, 1816-1824 (2010).

2) Adel-Patient $\mathrm{K}$, Créminon $\mathrm{C}$, Bernard H, Clément G, Négroni L, Frobert Y, Grassi J, Wal JM, Chatel JM. Evaluation of a high IgEresponder mouse model of allergy to bovine $\beta$-lactoglobulin BLG: development of sandwich immunoassays for total and allergenspecific IgE, IgG1 and IgG2a in BLG-sensitized mice. J. Immunol. Methods, 235, 21-32 (2010).

3) Mansueto P, Montalto G, Pacor ML, Esposito-Pellitteri M, Ditta V, Lo Bianco C, Leto-Barone SM, Di Lorenzo G. Food allergy in gastroenterologic diseases: Review of literature. World J. Gastroenterol., 12, 7744-7752 (2006).

4) Romagnani S. The increased prevalence of allergy and the hygiene hypothesis: missing immune deviation, reduced immune suppression, or both? Immunology, 112, 352-363 (2004).

5) Eisenstein EM, Williams CB. The Treg/Th17 cell balance: a new paradigm for autoimmunity. Pediatr. Res., 65 (Supplement), 26-31 (2009). 
6) Steinman L. A brief history of $\mathrm{T}(\mathrm{H}) 17$, the first major revision in the $\mathrm{T}(\mathrm{H}) 1 / \mathrm{T}(\mathrm{H}) 2$ hypothesis of $\mathrm{T}$ cell-mediated tissue damage. Nat. Med., 13, 139-145 (2007).

7) Nakae S, Komiyama Y, Nambu A, Sudo K, Iwase M, Homma I, Sekikawa K, Asano M, Iwakura Y. Antigen-specific T cell sensitization is impaired in IL-17-deficient mice, causing suppression of allergic cellular and humoral responses. Immunity, 17, 375-387 (2002).

8) Sakaguchi S, Ono M, Setoguchi R, Yagi H, Hori S, Fehervari Z, Shimizu J, Takahashi T, Nomura T. Foxp $3^{+} \mathrm{CD} 25^{+} \mathrm{CD} 4^{+}$naturalregulatory $\mathrm{T}$ cells in dominant self-tolerance and autoimmune disease. Immunol. Re., 212, 8-27 (2006).

9) Oboki K, Ohno T, Saito H, Nakae S. Th17 and allergy. Allergol. Int., 57, 121-134 (2008).

10) He R, Oyoshi MK, Jin H, Geha RS. Epicutaneous antigen exposure induces a Th17 response that drives airway inflammation after inhalation challenge. Proc. Natl. Acad. Sci. U.S.A., 104, 15817-15822 (2007).

11) Cheung PF, Wong CK, Lam CW. Molecular mechanisms of cytokine and chemokine release from eosinophils activated by IL-17A, IL-17F, and IL-23: implication for Th17 lymphocytes-mediated allergic inflammation. J. Immunol., 180, 5625-5635 (2008).

12) Yamamoto $Y$, Negoro $T$, Wakagi A, Hoshi A, Banham AH, Roncador G, Akiyama H, Tobe T, Sunaga S, Nakano Y, Itabashi K. Participation of Th17 and Treg cells in pediatric bronchial asthma. $J$. Health Sci., 56, 589-597 (2010).

13) Cross ML, Stevenson LM, Gill HS. Anti-allergy properties of fermented foods: an important immunoregulatory mechanism of lactic acid bacteria? Int. Immunopharmacol., 1, 891-901 (2001).

14) Kwona HK, Leea CG, Soa JS, Chaea CS, Hwanga JS, Sahooa A, Namb JH, Rheeb JH. Generation of regulatory dendritic cells and CD $4^{+}$Foxp $3^{+} \mathrm{T}$ cells by probiotics administration suppresses immune disorders. Proc. Natl. Acad. Sci. U.S.A., 5, 1-11 (2010).

15) Jan RL, Yeh KC, Hsieh MH, Lin YL, Kao HF, Li PH, Chang YS, Wang JY. Lactobacillus gasseri suppresses Th17 pro-inflammatory response and attenuates allergen-induced airway inflammation in a mouse model of allergic asthma. Br. J. Nutr., 108, 130-139 (2012).

16) López P, González-Rodríguez I, Gueimonde M, Margolles A, Suárez A. Immune response to Bifidobacterium bifidum strains support Treg/Th17 plasticity patricia. PLoS ONE, 6, 1-9 (2011).

17) Li AL, Meng XC, Guo L, Ma DX, Wang Y. Screening of $\beta$-lactoglobulin allergy-modulating lactobacilli strains using in vtro-in vivo correlation experiments. Acta Microbiol. Sin., 52, 104-110 (2012)

18) Lara-Villoslada F, Olivares M, Xaus J. The balance between caseins and whey proteins in cow's milk determines its allergenicity. $J$. Dairy Sci., 88, 1654-1660 (2005).

19) Duan CC, Huo GC, Yang LJ, Ren DX, Chen JL. Comparison of sensitization between $\beta$-lactoglobulin and its hydrolysates. Asian Pac. J. Allergy Immunol., 30, 32-39 (2012).

20) Cunningham-Rundles $S$, Ahrné $S$, Johann-Liang R, Abuav R, Dunn-Navarra AM, Grassey C, Bengmark S, Cervia JS. Effect of probiotic bacteria on microbial host defense, growth, and immune function in human immunodeficiency virus type-1 infection. Nutrients, 3, 1042-1070 (2011).

21) Flinterman $\mathrm{AE}$, Knol EF, van Ieperen-van Dijk AG, Timmerman HM, Knulst AC, Bruijnzeel-Koomen CA, Pasmans SG, van Hoffen E. Probiotics have a different immunomodulatory potential in vitro versus ex vivo upon oral administration in children with food allergy. Int. Arch. Allergy Immunol., 143, 237-244 (2007).

22) Sato $Y$, Akiyama $H$, Suganuma $H$, Watanabe $T$, Nagaoka $M H$, Inakuma T, Goda Y, Maitani T. The feeding of beta-carotene downregulates serum $\operatorname{IgE}$ levels and inhibits the type I allergic response in mice. Biol. Pharm. Bull., 27, 978-984 (2004).
23) Bettelli E, Carrier Y, Gao W, Korn T, Strom TB, Oukka M, Weiner HL, Kuchroo VK. Reciprocal developmental pathways for the generation of pathogenic effector TH17 and regulatory T cells. Nature, 441, 235-238 (2006).

24) Schmidt-Weber CB. Th17 and treg cells innovate the TH1/TH2 concept and allergy research. Chem. Immunol. Allergy, 94, 1-7 (2008).

25) Sélo I, Clément G, Bernard H, Chatel J, Créminon C, Peltre G, Wal J. Allergy to bovine beta-lactoglobulin: specificity of human IgE to tryptic peptides. Clin. Exp. Allergy, 29, 1055-1063 (1999).

26) Ochs HD, Oukka M, Torgerson TRT. Th17 cells and regulatory $T$ cells in primary immunodeficiency diseases. J. Allergy Clin. Immunol., 123, 977-983, quiz, 984-985 (2009).

27) Liang SC, Long AJ, Bennett F, Whitters MJ, Karim R, Collins M, Goldman SJ, Dunussi-Joannopoulos K, Williams CM, Wright JF, Fouser LA. An IL-17F/A heterodimer protein is produced by mouse Th17 cells and induces airway neutrophil recruitment. J. Immunol., 179, 7791-7799 (2007).

28) Ivanov II, McKenzie BS, Zhou L, Tadokoro CE, Lepelley A, Lafaille JJ, Cua DJ, Littman DR. The orphan nuclear receptor RORgammat directs the differentiation program of proinflammatory IL-17 ${ }^{+}$T helper cells. Cell, 126, 1121-1133 (2006).

29) Zheng Y, Josefowicz SZ, Kas A, Chu TT, Gavin MA, Rudensky AY. Genome-wide analysis of Foxp3 target genes in developing and mature regulatory T cells. Nature, 445, 936-940 (2007).

30) Dienz O, Rincon M. The effects of IL-6 on CD4 T cell responses. Clin. Immunol., 130, 27-33 (2009).

31) Pasare C, Medzhitov R. Toll pathway-dependent blockade of $\mathrm{CD} 4^{+} \mathrm{CD} 25^{+} \mathrm{T}$ cell-mediated suppression by dendritic cells. Science, 299, 1033-1036 (2003)

32) McGeachy MJ, Bak-Jensen KS, Chen Y, Tato CM, Blumenschein W, McClanahan T, Cua DJ. TGF-beta and IL-6 drive the production of IL-17 and IL-10 by T cells and restrain T(H)-17 cell-mediated pathology. Nat. Immunol., 8, 1390-1397 (2007).

33) Ziegler SF, Buckner JH. FOXP3 and the regulation of Treg/Th17 differentiation. Microbes Infect., 11, 594-598 (2009).

34) Fujiwara D, Inoue $S$, Wakabayashi H, Fujii T. The anti-allergic effects of lactic acid bacteria are strain dependent and mediated by effects on both Th1/Th2 cytokine expression and balance. Int. Arch. Allergy Immunol., 135, 205-215 (2004).

35) Segawa S, Nakakita Y, Takata Y, Wakita Y, Kaneko T, Kaneda $\mathrm{H}$, Watari J, Yasui H. Effect of oral administration of heat-killed Lactobacillus brevis SBC8803 on total and ovalbumin-specific immunoglobulin E production through the improvement of Th1/Th2 balance. Int. J. Food Microbiol., 121, 1-10 (2008).

36) Neveu WA, Allard JL, Raymond DM, Bourassa LM, Burns SM, Bunn JY, Irvin CG, Kaminsky DA, Rincon M. Elevation of IL-6 in the allergic asthmatic airway is independent of inflammation but associates with loss of central airway function. Respir. Res., 11, 28-38 (2010).

37) Pessi T, Sütas $Y$, Hurme M, Isolauri E. Interleukin-10 generation in atopic children following oral Lactobacillus rhamnosus GG. Clin. Exp. Allergy, 30, 1804-1808 (2000).

38) Smits HH, Engering A, van der Kleij D, de Jong EC, Schipper K, van Capel TM, Zaat BA, Yazdanbakhsh M, Wierenga EA, van Kooyk Y, Kapsenberg ML. Selective probiotic bacteria induce IL10 -producing regulatory $\mathrm{T}$ cells in vitro by modulating dendritic cell function through dendritic cell-specific intercellular adhesion molecule 3-grabbing nonintegrin. J. Allergy Clin. Immunol., 115, 1260-1267 (2005).

39) Lavasani S, Dzhambazov B, Nouri M, Fåk F, Buske S, Molin G, Thorlacius H, Alenfall J, Jeppsson B, Weström B. A novel probiotic mixture exerts a therapeutic effect on experimental autoimmune encephalomyelitis mediated by IL-10 producing regulatory $\mathrm{T}$ cells. PLoS ONE, 5, e9009 (2010). 